\title{
The Economy of Oaxaca in the Period 2004-2013: A Brief Review
}

\author{
Mario Rojas Miranda ${ }^{1}$, Edgar Manuel Cano Cruz ${ }^{2}$ \\ ${ }^{1}$ Public Administration Department, University of the Istmo Region, Ixtepec, Mexico \\ ${ }^{2}$ Computer Science Department, University of the Istmo Region, Ixtepec, Mexico \\ Email address: \\ mariorojas15@hotmail.com (M. R. Miranda), ie.edgarcano@gmail.com (E. M. C. Cruz)
}

\section{To cite this article:}

Mario Rojas Miranda, Edgar Manuel Cano Cruz. The Economy of Oaxaca in the Period 2004-2013: A Brief Review. International Journal of Economic Behavior and Organization. Vol. 3, No. 3, 2015, pp. 34-40. doi: 10.11648/j.ijebo.20150303.12

\begin{abstract}
Oaxaca is one of the most recognized states of Mexico, due to its gastronomic, cultural and environmental wealth. Located in the south of Mexico. The economic activities of Oaxaca is characterized by its own dynamic, far forms of production wave of globalization that began in Mexico from the decade of the eighties in the last century. In this paper, the population dynamics, GDP and income distribution of the inhabitants of the state of Oaxaca, in the period between of 2004-2013 is analyzed. The document is divided into three parts: the first deals with regard to production and economic growth, the second concerns the dynamics of the population, finally the third part closes with the conclusions of this paper.
\end{abstract}

Keywords: Oaxaca, Economy, Gross, Gross Domestic Product, Production

\section{Introduction}

Oaxaca is one of the most recognized in the country of Mexico states, due to its gastronomic, cultural and environmental wealth. Located in the south of Mexico (see Figure 1). The economic activities of Oaxaca is characterized by its own dynamic, near and far forms of production wave of globalization that began in Mexico from the decade of the eighties in the last century.

Mexico's economic growth has not occurred evenly, however it has generated some inequalities with more emphasis on states like Oaxaca $[1,2,3]$, resulting in low productivity, a value of product per capita and reduced income inequality in the population $[4,5]$ and greater emphasis on the Oaxaca women [6,7].

Oaxaca has the fourth largest commercial port in Mexico and an oil refinery. In addition, the state of Oaxaca houses an important part of indigenous population, which face economic hardship and difficulty surviving [8]. The press, television and electronic media have been responsible for placing Oaxaca between the national agenda, commenting on social issues.

However, there is a lack of productive activities in the state, agriculture, tourism, trade and the effects these variables have on their populations [9]. In this sense, the study of the local economy allows us to understand the origin of the lags in migration, employment and income of the Oaxaca people.

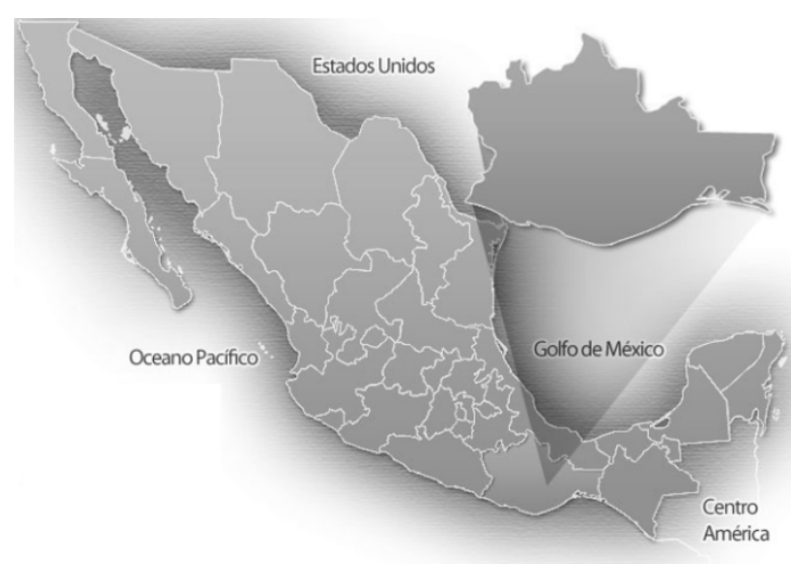

Figure 1. Location of Oaxaca in Mexico.

The present research focuses on analyzing the economy of Oaxaca to highlight their performance, their population dynamics, its per capita GDP and income distribution in the years 2004 to 2013 . The paper is organized as follows: the second section addresses the production and economic growth; the third section presents the characteristics of the population; the fourth section analyzes the per capita income and income distribution; finally, the fifth section concludes with this research. 


\section{Production of Oaxaca}

The economic performance of Mexico has been described by many analysts as weak and inadequate $[10,11]$, since the rate at which economic activities are expanding in Mexico is among the lowest in Latin America, which does not allow to cover the most basic needs of the population. In this sense, the rate at which GDP grows in Oaxaca is even slower, which gives an overview of the challenges facing the state.

Oaxaca's economy is relatively small, its size expressed through their gross domestic product (GDP) is 244000669 million for 2013, representing $1.6 \%$ of the national GDP [12]. Its value is below the state average output of 482 thousand 736 million pesos, of which 22 states have a higher GDP than that of Oaxaca and 11 states have a lower GDP (see Figure 2)

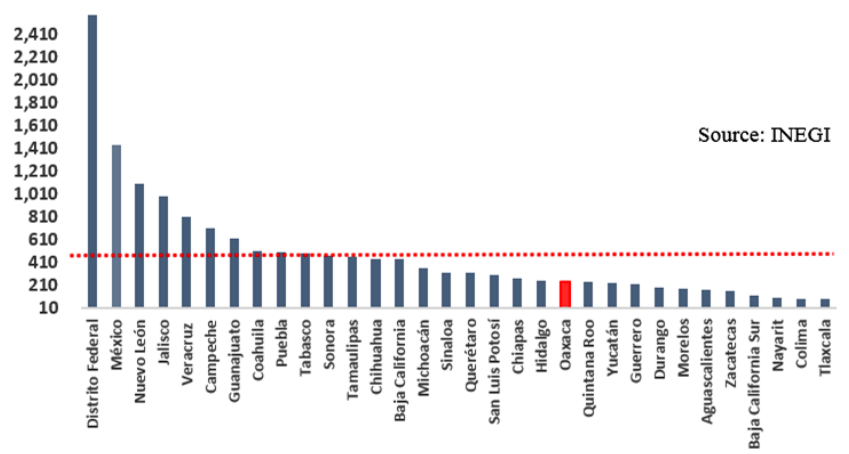

Figure 2. PIB of Mexico states (in millions of pesos).

Oaxaca's GDP equals one tenth of the Federal District GDP, a fifth of Nuevo León, a third of Campeche, the half of Tabasco, two thirds of Sinaloa, one and half times of Zacatecas. Internationally, Oaxaca GDP is half that of Cuba and has a size close to countries of Central America and the Caribbean [13]. In the last 10 years, the GDP of Oaxaca has had an average annual growth of $2 \%$, lower than that observed in the country $(2.7 \%)$. In the last decade, the volatility of national GDP (measured by its variance) is 8.5 ; while for the Oaxaca State is 2.3. Oaxaca's economy grows less about what the country is experiencing. However, the GDP of Oaxaca is more stable, with minor fluctuations in value, with less pronounced ups and downs. Unlike the national GDP, where it has ups and sharpest declines, making it more unstable (see Figure 3).

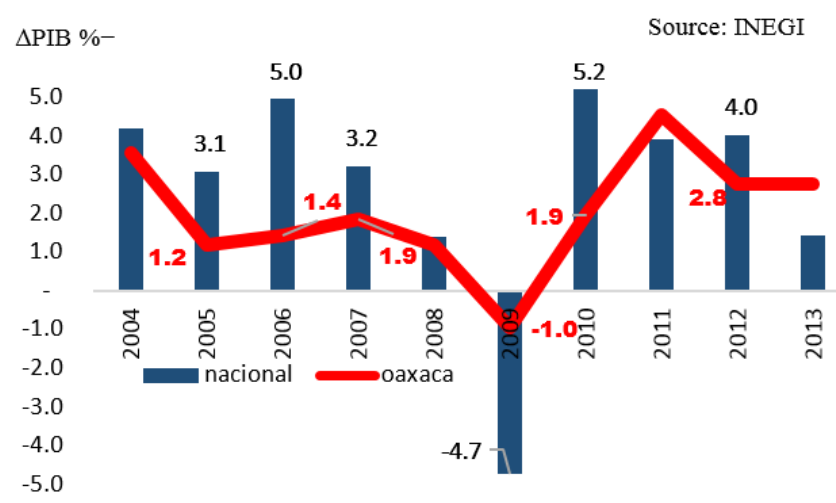

Figure 3. Growth of the country and Oaxaca in the period 2004-2013.
When the housing bubble burst in the US in the second half of 2007 [14]. The impact of this crisis, beat on the Mexico's economy until the second half of 2008 and more strongly the first of 2009.

The mortgage crisis triggered a financial meltdown impacting the production and employment sector. In this sense, the economic slowdown in the US affected sales of Mexico in that country, decreasing domestic production, slowed the flow of foreign exchange from tourism, direct and capital investments and remittances from Mexican citizens [15]. In this context, the interdependence between the external sectors, the export economy and the domestic market ended up rapidly slow the economy of Mexico. The degree of contagion finally manifested with a fall of the Mexican economy of $8.9 \%$ YoY and $-6.9 \%$ and $0.3 \%$ in the first and second quarter, respectively [15].

When the global economic boom ended derived from the crisis that erupted in the US, our country suffered the consequences, economic activity began to slow and fall in 2009 at a rate of $-4.7 \%$. However, in Oaxaca production decelerated at a slower rate and the drop was relatively mild, GDP fell by $1 \%$. Again Oaxaca decoupled of the national economy experiencing a minor crisis, which inevitably affected employment and incomes, but to a lesser extent the rest of the country.

Oaxaca observed in the crisis a lower level of remittance flows, lower domestic and international tourism, and low trade and to a lesser extent a decline in foreign investment. With the economic recovery that followed in 2010, the national economy had a bounce your production, GDP grew 5.2\% in the case of Oaxaca growth was only $1.9 \%$, nothing spectacular.

The dynamism of the national economy for the same periods was 3.6 and $3.2 \%$, respectively [16]. The greater dynamism of Oaxaca in the post-crisis period is due to increased public spending, restoring the flow of currency sent Oaxaca from the US to Mexico and strong amounts of foreign investment have arrived in the state with the highest force earlier this decade [17, 18].

As already noted, the value of GDP in Oaxaca in 2013 amounted to 244 thousand 669 million pesos in 2013, of which the primary sector contributes 14000567000000 , the secondary with 77000173000000 and the third with 152,000 million pesos, representing 631.5 and $62.5 \%$, respectively. The Oaxaca economy has focused predominantly on servicesfrom consulting to financial and stock market until the selling various items by retailers [19], where most of the output, employment and income are derived from the provision of services [20].

\section{The Population of Oaxaca}

The Oaxaca population quadrupled in the last century, went from 948,000 people in 1900 , to 1 million 727 thousand for the year 1960, 3 million 19 thousand for 1990, 3 million 800 thousand for 2010. Without however, the rate of growth of population Oaxaca observed was below that experienced the 
country. The country had its greatest population growth in its history during the sixties, seventies and eighties of the last century [12], the country observed growth rates of 35,38 and $38 \%$, respectively; Oaxaca while population expansion rates were $25.1,16.7$ and $17.5 \%$ respectively for the same period. In the last twenty years the population dynamics in the country did not cease, but slowed considerably at an average annual rate of $7.2 \%$ for Oaxaca it was $5.6 \%$. The data suggest that the population of Oaxaca grew at a slower pace than appeared nationally in the last century.

Now, Oaxaca is a state with a relatively small population, it is 3 million 986 thousand inhabitants by 2014 according to figures from the National Population Council (CONAPO) [21], representing 3.3\% of the population Total. However, it is located within the national average, which is 3 million 741 thousand. Only 9 states have a population greater than Oaxaca, which in descending order are: State of Mexico, Mexico City, Veracruz, Jalisco, Puebla, Guanajuato, Chiapas, Nuevo Leon and Michoacán. Only the first four together account for $40 \%$ of the total population. By contrast, 21 states have a lower population Oaxaca, in ascending order are: Colima, Baja California Sur, Campeche, Nayarit, Tlaxcala, Aguascalientes, Quintana Roo, Zacatecas, Durango, Morelos, Querétaro, Yucatán, Tabasco, San Luis Potosí, Hidalgo, Sonora, Coahuila, Sinaloa, Baja California and Tamaulipas. The first four together not cover the population of Oaxaca (see Figure 4).

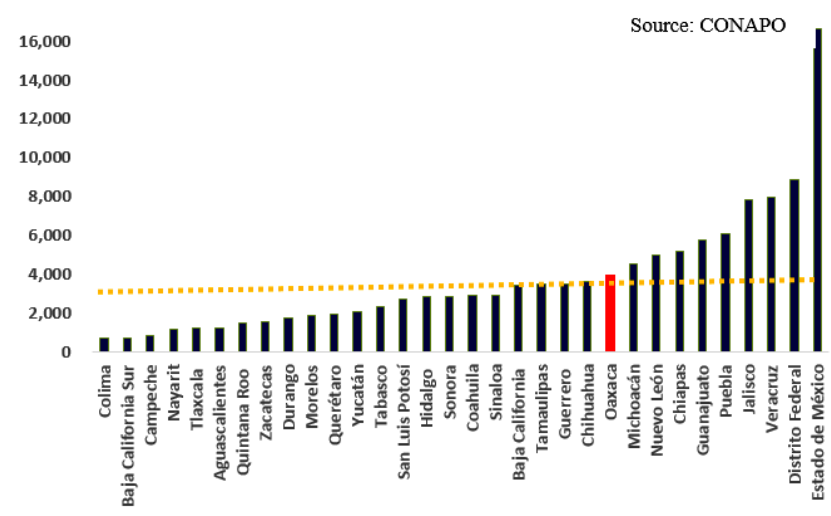

Figure 4. Population of Mexican states in 2014 (in thousands of persons).

In the entity $60 \%$ of the population live in towns with less than 15,000 inhabitants and the remaining $40 \%$ is based in metropolitan areas, conurbations and towns above of 15,000. It is widely known that Oaxaca is characterized by the large dispersion of its population sample of this is the concentration of 570 municipalities, the largest number available to a state alone.

Definitely one of the challenges facing the authorities to carry out services like education, health, housing, to name a few [12]. The $30 \%$ of the population are children between 0 and 14 years old, $60 \%$ are between 15 and 65 years and only $8 \%$ are over 65 . This is a population that is predominantly in their productive years. The average life expectancy is 77 years [21].

According to the INEGI in 2014, 20 babies were born in
Oaxaca live births per 1000 inhabitants in states like Guerrero, Chiapas and Mexico City the figure is 21, 22 and 18, respectively [12]. In this sense, the Oaxacan people have on average 2.4 children, this figure has not had significant changes if we consider that in 2007 the number was 2.7.

However the natural growth of the population, Oaxaca has a net negative migration balance. According to CONAPO, "In the past eight years 41,000 women left the state, the reasons are many, among them surely is the search for better opportunities." However, this figure is lower than other states like Chiapas and Guerrero experienced for the same period, which amounted to 104,000 and 115,000 inhabitants, respectively.

Within Mexico migration of people from one state to another is a phenomenon that not only occurs in Oaxaca, Chiapas and Guerrero but in all institutions of the republic. In this contexts, the states receiving the Oaxacan people who decide to change their place of residence are: State of Mexico, Nuevo León, Querétaro and Quintana Roo [12]. Only the State of Mexico, Querétaro Quintana Roo and received in the last eight years $437000,180 \quad 000$ and 77000 inhabitants respectively.

\section{The Per Capita GDP and Income}

Oaxaca has a relatively low per capita GDP is the second lowest in the country. According to the INEGI, the amounts in 2013 to 52,000 pesos at 2008 prices, higher than that recorded only 45 thousand pesos Chiapas.

The low per capita GDP is explained by the low production of goods and services in the state, low productivity that characterizes agricultural activities (which are labor intensive and no use of technology), production is predominantly subsistence and domestic food market is satisfied with goods from other states (Rojas 2006).

As already noted, Oaxaca concentrated more than half of productive activities in the area of services, however these are not specified, have low productivity and provide very little benefit compared to the benefits offered by new technologies information. Trade is one of them provides abundant sources of employment for the population but many of these businesses are in the ranks of informality, lack access to credit and are mostly family businesses that fail to stay long on the market (Rojas, 2009).

The entity represents $3.3 \%$ of the population and contributes only $1.6 \%$ of the total production of Mexico. The result has certainly been to Oaxaca generates a value of product per capita very low. In fact Chiapas, Oaxaca and Guerrero are the three states in that order having the lowest income per capita. Even well below the national average in 2013 amounted to 105,000 pesos prices 2008. Following this indicator for 2013, in Oaxaca the value of per capita accounted for three quarters of the State of Mexico, half of Chihuahua, third of Coahuila and a fifth of the Federal District (see Figure 5).

The Oaxacan average product has grown very little in recent years, from 2005-2013 increased by 2000 pesos, went 
from 50,000 to 52,000 pesos at 2008 prices, representing an increase of $3 \%$, below the increase experienced by the country in the same period, which was $5.3 \%$.

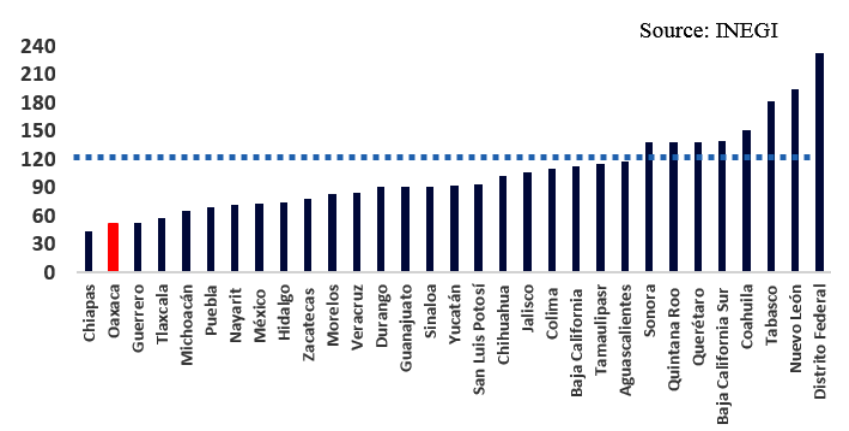

Figure 5. GDP of the states of Mexico (in thousands of pesos).

Other entities experienced an even greater growth, as in the case of Querétaro 18.5\%, 17.4\% Aguascalientes, San Luis Potosí and Guanajuato $14.8 \%$ to $11.8 \%$, benefiting from the export drive experiencing the country and linked to the production chains worldwide for products such as cars, electronics and aircraft parts, to name just a few [13].

Our country still marked by the phenomenon of inequality in its various forms, such as social, productive and income and Oaxaca is no exception. According to INEGI: "people who report receiving income in the state by $201470 \%$ of the population earns up to 3 minimum wages, $21 \%$ of 3-5 minimum wages and only $9 \%$ had incomes of more than 5 minimum wages". However, inequality is a general feature facing the whole country, but in states like Oaxaca this is accentuated [21]. Economic inequality is a phenomenon that enables the development of societies because people can not afford education, health or access to housing [22].

Likewise, inequality acts as a brake to increase the domestic market because people do not have the resources to raise their demand for goods and services. In 2007, two years before the financial meltdown of US, $54 \%$ of the population received up to 3 minimum wages, $27 \%$ of $3-5$ salaries and the remaining $19 \%$ more than 5 minimum wage [23].

The crisis certainly affected the category of people who received more income, which rose from $19 \%$ in 2007 to $9 \%$ in 2014 , leading them to focus on lower-income areas.
In 2014 , the people who get up a minimum wage $45 \%$ are men and the rest women, group 1 and up to 2 minimum wages are $49 \%$ male and $51 \%$ female, over 2 and up March salaries $59 \%$ are men and the rest women. In the first and second item of income participation of women and men is almost equal. A feature of the region is certainly strong incorporation of women into productive activities, in fact, she excels in many areas of state life [24].

Moreover, in the area of income of more than 2 to 3 minimum wages, the participation of women starts to lag. For the year 2014, 66\% are men and the remaining $34 \%$ are women, three quarters this inequality is further exacerbated when the last two income ranges, 3 and up to 5 salaries and wages is observed 5 onwards parties of those receiving the highest incomes are men and the rest women (see Table 1).

The fact that women are concentrated in lower income levels and is limited to high income is explained by several reasons, among them are the lack of education, poor preparation to perform any productive work, have children at an early age, jobs they perform are unsophisticated and generate little added value, productivity is very low, excel work and family sexism, among other factors [25].

\section{Conclusions}

Oaxaca has a relatively small economy in 2013 accounted for $1.6 \%$ of national production. In the last decade, economic performance ran at a slower rate than the national average; likewise, the GDP of Oaxaca is known for being more stable and less volatile.

This is because Oaxaca is partially decoupled from the economic dynamics of the country, earning him first, better weather the economic crisis of 2009; however, it does not benefit the country booms product of its connection to the world market that ties through exports and the inflow of foreign capital.

Oaxaca has a tertiary economy, ie dominated by productive activities linked to services. However, they are characterized by low added value and reduced productivity.

In the last century the population of Oaxaca grew at a slower pace than what was experienced nationwide.

Table 1. Income of the employed population of Oaxaca, 2007-2014.

\begin{tabular}{|c|c|c|c|c|c|c|c|c|c|c|c|c|c|c|c|}
\hline \multirow{2}{*}{ year } & \multicolumn{3}{|c|}{1 minimum wage } & \multicolumn{3}{|c|}{1 to 2 minimum wages } & \multicolumn{3}{|c|}{2 to 3 minimum wages } & \multicolumn{3}{|c|}{3 to 5 minimum wages } & \multicolumn{3}{|c|}{ more than 5 minimum wages } \\
\hline & $\mathbf{T}^{*}$ & $\mathbf{M} * *$ & $W^{* * *}$ & $\mathbf{T}$ & $\mathbf{M}$ & $\mathbf{W}$ & $\mathbf{T}$ & $\mathbf{M}$ & $\mathbf{W}$ & $\mathbf{T}$ & $\mathbf{M}$ & $\mathbf{W}$ & $\mathbf{T}$ & $\mathbf{M}$ & $\mathbf{W}$ \\
\hline 2007 & 17 & 48 & 52 & 10 & 49 & 51 & 27 & 59 & 41 & 27 & 73 & 27 & 19 & 76 & 23 \\
\hline 2008 & 17 & 45 & 55 & 13 & 48 & 52 & 25 & 62 & 38 & 26 & 72 & 28 & 20 & 75 & 25 \\
\hline 2009 & 20 & 44 & 56 & 13 & 54 & 46 & 25 & 62 & 38 & 26 & 73 & 27 & 16 & 74 & 26 \\
\hline 2010 & 18 & 45 & 55 & 13 & 50 & 50 & 27 & 65 & 35 & 27 & 72 & 28 & 15 & 74 & 26 \\
\hline 2011 & 20 & 42 & 58 & 17 & 50 & 50 & 27 & 63 & 37 & 25 & 74 & 26 & 11 & 74 & 26 \\
\hline 2012 & 20 & 42 & 58 & 17 & 50 & 50 & 27 & 63 & 37 & 25 & 74 & 26 & 11 & 74 & 26 \\
\hline 2013 & 19 & 44 & 56 & 18 & 51 & 49 & 27 & 65 & 35 & 24 & 73 & 27 & 12 & 72 & 28 \\
\hline 2014 & 20 & 45 & 55 & 20 & 49 & 51 & 31 & 66 & 34 & 21 & 75 & 24 & 9 & 76 & 24 \\
\hline
\end{tabular}

* Total persons, $\mathrm{M}^{* *}$ Men in percentage, $\mathrm{W}^{* * *}$ Women in percentage. Source: CONAPO. 
The entity is very close to 4 million of people, are expected to reach by 2015 . Its population represents $3.3 \%$ of the total population is 120 million. The number of inhabitants is near the national average. Its people are mostly young people who are in their most productive years, which sits at $60 \%$ in rural communities. The enormous dispersion of its population is something that unlike the rest of the other entities. Oaxaca has a negative migration balance, ie, drives people towards others and the US.

Oaxaca has a per capita GDP relatively low, for 2013 amounted to 52,000 pesos at 2008 prices, in fact it is the second lowest, less than Chiapas and upper Guerrero, these two occupy the first and third lowest in the country. This can be explained because their productive activities generate little added value, are labor-intensive, low-tech feature and have very low productivity. The product for habitant has hardly grown over the past eight years, increased by $3 \%$, which was lower than that experienced the country was $5.3 \%$ or other entities as Querétaro and Aguascalientes with dramatic increases in 18.5 and $17.4 \%$, respectively for the same period as a result of its export local economies linked to the world market by producing cars, electronics and aerospace development in Mexico.

Inequality of income of the employed population in Oaxaca is a notable feature in $201470 \%$ of the population earns up to 3 minimum wages, $21 \%$ of $3-5$ wages and only $9 \%$ over 5 minimum wages. However this inequity, the situation is particularly acute when the approach genre in the workplace is incorporated. In the areas of higher incomes, ie from 3-5 wages and salaries than 5 in these two women participate with only $35 \%$ percent, the rest are men. Certainly the low level of education, early incorporation of women into motherhood, and little training, discrimination and sexism family have prevented the Oaxacan women to improve their economic status. All these economic indicators to allow elements to understand why Oaxaca account along with Guerrero and Chiapas with a lower level of economic development compared to other states. Certainly the challenge facing policymakers and decision makers at the state and federal level is enormous.

\section{References}

[1] Chiquiar, D. (2008). Globalization, regional wage differentials and the Stolper-Samuelson Theorem: Evidence from Mexico. Journal of International Economics, 74(1), 70-93. doi:10.1016/j.jinteco.2007.05.009

[2] King, S., \& Sastré-Gutiérrez, M. (2010). Interregional Inequality Dynamics in Mexico. Spatial Economic Analysis, 5(1), 277-298. doi:10.1080/17421772.2010.493955

[3] Feinman, G., Nicholas, L., \& Haines, H. (2006). Socioeconomic Inequality and the Consumption of Chipped Stone at El Palmillo, Oaxaca, Mexico. Latin American Antiquity, 17(1), 151-175.
[4] Soto, A. (2015). Empresas Comunitarias en la Sierra Norte del Estado de Oaxaca. In Congreso Virtual sobre Cuerpos Académicos y Grupos de Investigación en Iberoamérica, 1.

[5] Velasco, R., Díaz, M., \& Hernández, P. (2013). Crisis agrícola y estructura regional en Guerrero y Oaxaca. Nicolaita de Estudios Económicos, 4(1), 141-158.

[6] Dema Moreno, S., Martínez, D., \& Finkel, L. (2015). Desigualdades de género en la distribución de los recursos económicos en las parejas. Revista Mexicana de Sociología, $100,53-73$.

[7] Rodríguez, P. A. (2015). Diálogos interculturales: Testimonios de mujeres indígenas. REVISTA DE ESTUDIOS DE GÉNERO. LA VENTANA, 95-133.

[8] Contreras, A. (2004). El cotidiano. Retrieved 2015, from http://www.elcotidianoenlinea.com.mx/pdf/12612.pdf

[9] Aquino, A. (2015). Alejandra Aquino Moreschi. Pueblos y fronteras, $9(18), 120-124$.

[10] e-consulta. (2014). e-consulta. Retrieved 2015, from Tendrá Mexico crecimiento mediocre por su modelo económico: http://e-oaxaca.com/medios-externos/2014-05-26/tendra-mexi co-crecimiento-mediocre-por-su-modelo-economico

[11] GrupoFórmula. (2014). Crecimiento mediocre del PIB. Retrieved 2015, from http://www.radioformula.com.mx/notas.asp?Idn=435822\&idF $\mathrm{C}=2014 \& \mathrm{sURL}=$

[12] INEGI. (2014). Instituo Nacional de Estadística y Geografía. Retrieved 2015, from http://www.inegi.org.mx/

[13] SE. (2014). Economy Activity of Oaxaca. Retrieved 2015, from Mexican Department of Economy: http://www.economia.gob.mx/delegaciones-de-la-se/estatales/ oaxaca\#

[14] Ducaa, J., Muellbauerc, J., \& Anthony, M. (2010). Housing markets and the financial crisis of 2007-2009: Lessons for the future. Journal of Financial Stability, 6(4), 203-217.

[15] Rojas, M. (2015). El debate de las causas de la crisis financiera de Estados Unidos del 2008. ¿Fue adecuada la respuesta del FED? Perspectivas, 8(2). Facultad de Economía, México.

[16] SEGOB. (2013). La energía éolica en México. Retrieved 2015, from Secretaria de gobernación. Doi:10.1016/S0301-7036(14)70879-X

[17] Howe, C. (2014). Anthropocenic Ecoauthority: The Winds of Oaxaca. Anthropological Quarterly, 87(2), 381-404.

[18] Díaz-Cayeros, A., Magaloni, B., \& Ruiz-Euler, A. (2014). Traditional Governance, Citizen Engagement, and Local Public Goods: Evidence from Mexico. World Devvelopment, 53, 1-112. doi:10.1016/j.worlddev.2013.01.008

[19] Murphy, A. D., Silva, I. R., Morales, R. R., Gil, J. L., \& and Segura, J. J. (2015). The Urban System in the Central Valleys of Oaxaca. Economic Anthropology, 2(1), 84-96. doi:10.1002/sea2.12019

[20] Rojas, M. (2009). "La banca de desarrollo en México 1940-2009: ¿Instrumento para el desarrollo?”, Economía Informa, 361 (1), Facultad de Economía, México. 
[21] SEGOB. (2015). Consejo nacional de población. Retrieved 2015, from http://www.conapo.gob.mx/.

[22] Bourguignon, F., Ferreira, F., \& Leite, P. (2007). Beyond Oaxaca-Blinder: Accounting for differences in household income distributions. The Journal of Economic Inequality, 6(2), 117-148. doi:10.1007/s10888-007-9063-y.

[23] Feinman, G., Nicholas, L., \& Haines, H. (2006). Socioeconomic Inequality and the Consumption of Chipped Stone at El Palmillo, Oaxaca, Mexico. Latin American Antiquity, 17(1), 151-175.
[24] DENUE. (2014). Directory of National Stadistic of Economic Units, Mexico. Retrieved 2015, from http://www.inegi.org.mx/est/contenidos/proyectos/denue/prese ntacion.aspx.

[25] Rodríguez, P. A. (2015). Diálogos interculturales: Testimonios de mujeres indígenas. revista de estudios de género. la ventana, 95-133.

[26] Paz, Y., \& Mejía, A. (2012). las mujeres oaxaqueñas: entre la discriminación y la pobreza. (utm, ed.) Retrieved 2015, from http://www.eumed.net/rev/cccss/21/pcma.pdf. 